$-\quad$ Subject Category: METALLURGY AND CERAMICS

UNITED STATES ATOMIC ENERGY COMMISSION

TRANSFORMATION KINETICS OF

URANIUM-MOLYBDENUM ALLOYS

By

H. A. Saller

F. A. Rough

A. A. Bauer

October 21, 1954

Battelle Memorial Institute

Columbus, Ohio

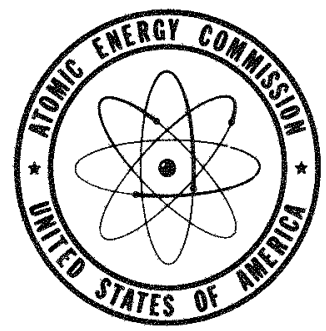

Technical Information Service, Oak Ridge, Tennessee 


\section{DISCLAIMER}

This report was prepared as an account of work sponsored by an agency of the United States Government. Neither the United States Government nor any agency Thereof, nor any of their employees, makes any warranty, express or implied, or assumes any legal liability or responsibility for the accuracy, completeness, or usefulness of any information, apparatus, product, or process disclosed, or represents that its use would not infringe privately owned rights. Reference herein to any specific commercial product, process, or service by trade name, trademark, manufacturer, or otherwise does not necessarily constitute or imply its endorsement, recommendation, or favoring by the United States Government or any agency thereof. The views and opinions of authors expressed herein do not necessarily state or reflect those of the United States Government or any agency thereof. 


\section{DISCLAIMER}

Portions of this document may be illegible in electronic image products. Images are produced from the best available original document. 


\section{2}

Date Declassified: August 4, 1955.

The Atomic Energy Commission makes no representation or warranty as to the accuracy or usefulness of the information or statements contained in this report, or that the use of any information, apparatus, method or process disclosed in this report may not infringe privately-owned rights. The Commission assumes no llability with respect to the use of, or for damages resulting from the use of, any information, apparatus, method or process disclosed in this report.

This report hes been reproduced directly from the best available copy.

Reproduction of this information is encouraged by the United States Atamic Fnergy Commission. Arrangements for your republication of this document in whole or in part should be made with the author and the organization ho represents.

Issuance of this document does not constitute authority for declassification of classified material of the same or similar content and title by the same authors.

Since nontechnical and nonessential prefatory material has been deleted, the first page of the report is page 5 .

Printed in USA, Price 25 cents. Available from the Office of Technical Services, Department of Commerce, Washington 25, D. C. 
Contract No. W-7405-eng-92

\section{TRANSFORMATION KINETICS OF URANIUM-MOLYBDENUM ALLOYS}

by

H. A. Saller

F. A. Rough

A. A. Bauer

October 21,1954

BATTELLE MEMORIAL INSTITUTE

$505 \mathrm{King}$ Avenue

Columbus 1, Ohio 
TABLE OF CONTENTS

Page

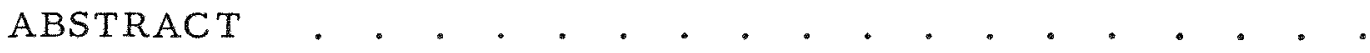

INTRODUCTION . . . . . . . . . . . . . . . . . . 7

EXPERIMENTAL METHOD . . . . . . . . . . . . . 9

Alloy and Specimen Preparation. . . . . . . . . . 10

Isothermal-Transformation Technique. . . . . . . 10

Metallographic Preparation . . . . . . . . . . 11

RESULTS AND DISCUSSION . . . . . . . . . . . . . 11

Uranium-21 a/o Molybdenum Alloy . . . . . . . . 12

Uranium-26. 4 and -30 a/o Molybdenum Alloys . . . . . 12

SUMMARY AND CONCLUSIONS . . . . . . . . . . . 25

REFERENCES . • . . . . . . . . . . . . . . . 26 


\title{
TRANSFORMATION KINETICS OF URANIUM-MOLYBDENUM ALLOYS
}

\author{
H. A. Saller, F. A. Rough, and A. A. Bauer
}

\begin{abstract}
The kinetics and mode of transformation of metastable gamma in the uranium-molybdenum system have been investigated. Electricalresistance measurements made during isothermal transformation, supported by metallographic and hardness data, indicate the gamma-todelta transformation to be an ordering reaction which probably proceeds by nucleation and growth of the ordered phase. A "C-curve" type bebavior for the transformation is inferred from resistance measurements and metallograpbic observations of the 30 a/o alloy. An aging effect is attributed to coberency stresses in the matrix prior to precipitation of the ordered pbase. The gamma phase of the 21 a/o molybdenum alloy decomposes by a nucleation and growth mechanism to yield a lamellar distribution of the alpha and delta phases. The ordered, intermediate phase, delta, is body-centered tetragonal with $a_{o}=6.84 \mathrm{~A}$ and $c_{0}=6.55 \mathrm{~A}$. The solubility limits on the bigb-uranium side of the delta pbase are substantiated.
\end{abstract}

\section{INT RODUCTION}

Early investigators $(1) *$ of the uranium-molybdenum system reported that the addition of 20 to 30 a/o molybdenum stabilized gamma uranium down to room temperature. However, it has been shown $(2)$ that the gamma phase is metastable, and decomposes to form an intermediate body-centered tetragonal phase on long-time annealing below $580 \mathrm{C}$. Figure 1, based on more recent investigations $(3,4)$, shows the delta phase in the uraniummolybdenum system. The limits of this phase lie between 19 and 34 a/o molybdenum at $575 \mathrm{C}$, the uranium solubility decreasing to about $31 \mathrm{a} / \mathrm{o}$ molybdenum at $400 \mathrm{C}$.

$X$-ray data for the transformed delta phase are given in Table 1 . The $X$-ray diffraction pattern(2) was indexed on a body-centered tetragonal net, giving a body-centered cell of $\mathrm{a}_{0}=6.84 \mathrm{~A}$ and $\mathrm{c}_{0}=6.55 \mathrm{~A}$. This was a doubling of the unit cell dimensions reported by Tucker(5) as $a_{0}=3.42 \mathrm{~A}$ and $c_{O}=3.278 \mathrm{~A}$, and of Pfeil and Browne $(4)$ as $a_{O}=3.425 \mathrm{~A}$ and $c_{0}=3.282 \mathrm{~A}$. It was not clear, on the basis of these results, however, whether doubling was due to a complex cell or superlattice formation during ordering.

*References are given at the end of the report. 


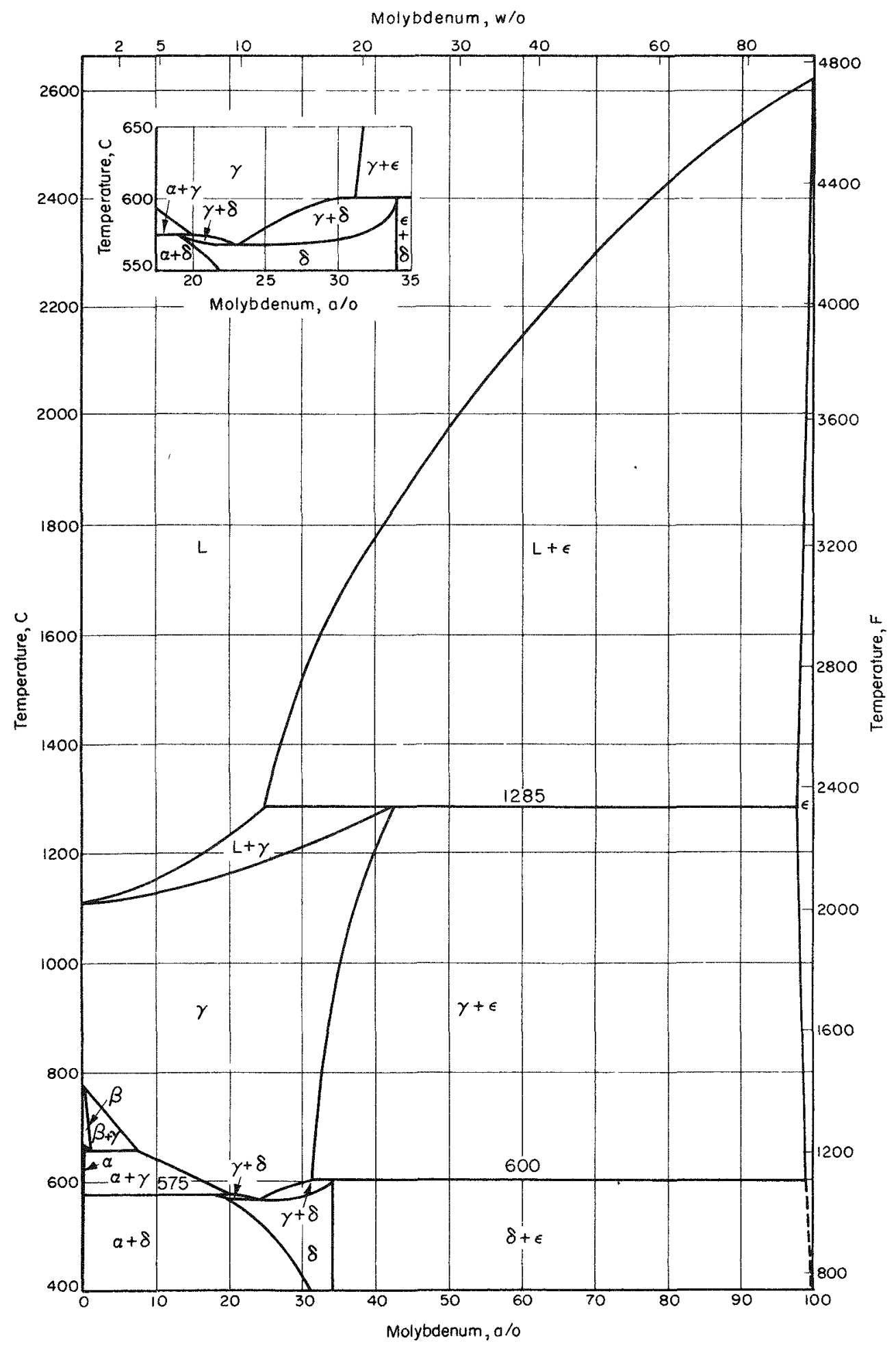

FIGURE I. URANIUM - MOLYBDENUM CONSTITUTION DIAGRAM 
TABLE 1. X-RAY DIFFRACTION PATTERN OF DELTA PHASE

\begin{tabular}{lcc}
\hline \multicolumn{3}{c}{$\begin{array}{c}\text { Body-Centered Tetragonal, } \\
\mathrm{c}_{\mathrm{O}}=6.55 \mathrm{~A}, \mathrm{a}_{\mathrm{O}}=6.84 \mathrm{~A}, \mathrm{Fe}-\mathrm{K}\end{array}$} \\
\hline (hk1) & Relative Intensity(a) & Spacing, d \\
\hline 110 & $\mathrm{~F}$ & 4.85 \\
002 & $\mathrm{VF}$ & 3.25 \\
220 & $\mathrm{MS}$ & 2.44 \\
202 & $\mathrm{~S}$ & 2.39 \\
130 & $\mathrm{~F}$ & 2.17 \\
400 & $\mathrm{M}$ & 1.72 \\
004 & $\mathrm{MF}$ & 1.65 \\
422 & $\mathrm{~S}$ & 1.39 \\
224 & $\mathrm{M}$ & 1.35 \\
440 & $\mathrm{MF}$ & 1.21 \\
404 & $\mathrm{M}$ & 1.18 \\
620 & $\mathrm{~S}$ & 1.08 \\
602 & $\mathrm{~S}$ & 1.04 \\
206 & $\mathrm{MW}$ & 0.97 \\
444 & $\mathrm{M}$ & \\
\hline \hline
\end{tabular}

(a) $S=$ strong, $M=$ medium, $F=$ faint, $W=$ weak, and $\mathrm{V}=$ very.

This investigation was undertaken to determine the nature of the transformation product and the kinetics of the metastable-gamma decomposition. Recently, alloys in this range became of interest because of their corrosion resistance to high-temperature water, and are being considered for possible application in the Pressurized Water Reactor.

\section{EXPERIMENTAL METHOD}

As the electrical resistivity of alloys is highly sensitive to structural change, and is readily measured, this property was selected as the one to be followed during isothermal transformation. Metallographic observations and hardness measurements were made to supplement the resistance data obtained. 
Alloy and Specimen Preparation

Alloys for this investigation were prepared from selected biscuit uranium.

Alloys were arc melted from five to seven times under a helium atmosphere, finally being cast into a 2 -in. wire bar. A zirconium getter button was used to clean the furnace atmosphere prior to melting.

The wire bars were hot rolled, from a helium-atmosphere furnace at $980 \mathrm{C}$, to $1 / 4-\mathrm{in}$. rod. The rods were pickled to remove oxide and a sample was taken for chemical analysis. All samples were analyzed for molybdenum and carbon content. Carbon contents ranged from 0.01 to $0.03 \mathrm{w} / \mathrm{o}$ carbon. Initially three compositions were selected for study: $21 \mathrm{a} / \mathrm{o}$ $(9.8 \mathrm{w} / \mathrm{o}), 26.4 \mathrm{a} / \mathrm{o}(12.6 \mathrm{w} / \mathrm{o})$, and $30 \mathrm{a} / \mathrm{o}(14.8 \mathrm{w} / \mathrm{o})$ molybdenum. Later work was confined to the $30 \mathrm{a} / \mathrm{o}$ alloy when it was found that this composition was more closely centered in the delta region.

All alloys were homogenized $5 \mathrm{hr}$ at $1060 \mathrm{C}$. Resistance specimens, 2-1/4 in. long, of dumbbell shape, with the central 1-3/4-in. length 0.050 in. in diameter, were machined from the 1/4-in. rod. All specimens, as well as additional samples for later heat treatment, were then annealed $4-1 / 2 \mathrm{hr}$ at $800 \mathrm{C}$ and water quenched. These heat treatments were carried out in a vacuum furnace under a pressure of $5 \times 10^{-5} \mathrm{~mm}$ mercury or less. Any surface film, formed during quenching, was removed by an electrolytic pickle.

Is othermal-Transformation Technique

The resistance specimens were isothermally transformed by inserting them in a Vycor U-tube which was placed in a lead bath held at the desired temperature of transformation. A stirrer in the lead bath, directly below the U-tube, served to eliminate gradients in the bath and also permitted closer temperature control of the bath. The U-tube was kept under a dynamic vacuum of about $10^{-5} \mathrm{~mm}$ of mercury. The specimens remained bright and shiny even after $500 \mathrm{hr}$ at temperature.

Resistance measurements were made by the potentiometric method. Tantalum current leads and voltage probes were spot welded to the ends of the resistance specimens. A low-discharge battery was used as the current source, and voltage readings to five and six significant figures on the standard resistance and resistance specimen, respectively, were made by means of an $\mathrm{L}$ and $\mathrm{N}$ Type $\mathrm{K}-2$ potentiometer. 
Readings were taken at temperature every $3 \mathrm{hr}$, except at the start of transformation, when readings were taken at shorter intervals. Alternate resistance readings were taken, in which the flow of current through the specimen was reversed, to eliminate the effect of spurious potentials arising as a result of any temperature gradient across the specimen. A thermocouple, spot welded to the specimen, was used to measure the specimen temperature. It was found that less than $5 \mathrm{~min}$ was required for the specimen to come to the bath temperature.

Upon completion of a run, additional samples were prepared for metallographic examination, along with the transformed specimen. These were transformed at the temperature of interest for times selected on the basis of the resistance changes observed. They were examined metallographically and hardness measurements were made.

\section{Metallographic Preparation}

Specimens for metallographic examination were ground wet through 600-grit paper and given a final polish on Forstmann cloth covered with diamond abrasive.

The $21 \mathrm{a} / 0$ molybdenum alloy was etched electrolytically at $20 \mathrm{v}$ with a mixture (by volume) of 1 part chromic acid base solution to 18 parts acetic acid. The base solution consisted of $118 \mathrm{~g}$ of chromic oxide dissolved in $100 \mathrm{~cm}^{3}$ water.

For all other alloys, the most satisfactory etchant was found to be one consisting of equal parts, by volume, of hydrogen peroxide and ammonium hydroxide. It was applied by swabbing.

The specimens were examined both under bright field and polarized light. Polarized-light techniques were found to be the most satisfactory for observation of the 26.4 and 30 a/o alloys. The etchant described above was used in all cases to remove worked metal from the surface prior to examination.

\section{RESULTS AND DISCUSSION}

Alloys containing $21,26.4$ and 30 a/o molybdenum were isothermally transformed at $500 \mathrm{C}$ and electrical resistance and metallographic data obtained for their transformation. When metallographic examination of the transformed structures showed the $30 \mathrm{a} / \mathrm{o}$ alloy to be the only one that was single phase, all further effort was concentrated on this composition. 
Additional data, during transformation at 540, 440, and $400 \mathrm{C}$ were obtained for this alloy. No attempt was made to obtain data at still lower temperatures when the transformation at $400 \mathrm{C}$ was found to be exceedingly sluggish.

\section{Uranium-21 a/o Molybdenum Alloy}

Electrical resistance and Vickers hardness, versus the logarithm of the time, are plotted in Figure 2 for the $21 \mathrm{a} / 0$ molybdenum alloy. The resistance curve shows an induction period, a transformation period, and finally a stage of no further change once transformation is complete. The hardness changes follow the resistance changes quite closely, a slight softening, once transformation is complete, probably resulting from coalescence of the precipitated particles.

This S-type transformation curve is typical of transformation occurring by a nucleation and growth mechanism. If the resistance change is assumed proportional to transformation, and is then plotted on a probability scale versus log time, a straight line results as shown in Figure 3 . White(6) obtained a similar decomposition curve for the nucleation and growth of alpha in beta uranium-chromium alloys during isothermal transformation.

If 1 per cent of the resistance change is taken as the beginning of transformation, and 99 per cent as the end of transformation, it is found that the transformation begins in $27 \mathrm{hr}$ and ends at about $170 \mathrm{hr}$. If comparison of these times is made with the times required to obtain the microstructures shown in Figure 4 , it is seen that good agreement exists between the two. The transformed structure consists of lamellar alpha-uranium and delta phases, which are nucleated at the gamma grain boundaries and grow inward to consume the gamma grain. After $80 \mathrm{hr}$ at temperature, the initially equiaxed metastable gamma grains show somewhat less than 50 per cent decomposition (Figure 4b) whereas after $170 \mathrm{hr}$ the alloy is apparently fully transformed (Figure 4c).

There is excellent agreement between resistance, hardness, and metallographic data obtained for this alloy. This agreement tends to validate the experimental techniques used to follow the transformation.

$$
\text { Uranium-26.4 and }-30 \text { a/o Molybdenum Alloys }
$$

In the $26.4 \mathrm{a} / 0$ alloy, transformed at $500 \mathrm{C}$, the resistance increased for the first $55 \mathrm{hr}$ and then decreased (Figure 5). The resistance showed an initial 1.34 per cent increase followed by a 0.6 per cent decrease. 


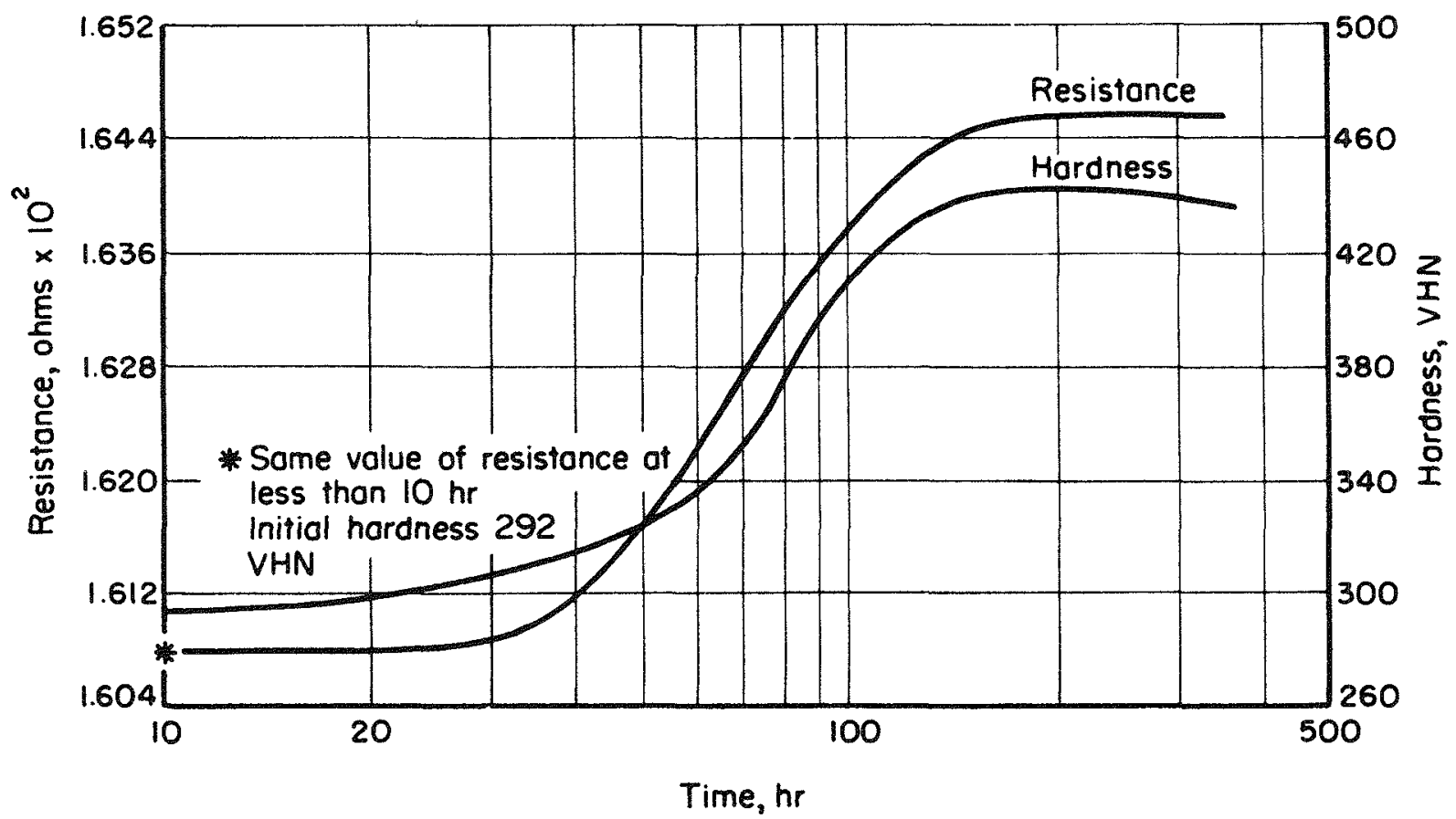

FIGURE 2. RESISTANCE AND HARDNESS CURVES OF A 21 a $/ 0$ MOLYBDENUM SAMPLE DURING ANNEALING AT $500 \mathrm{C}$ 


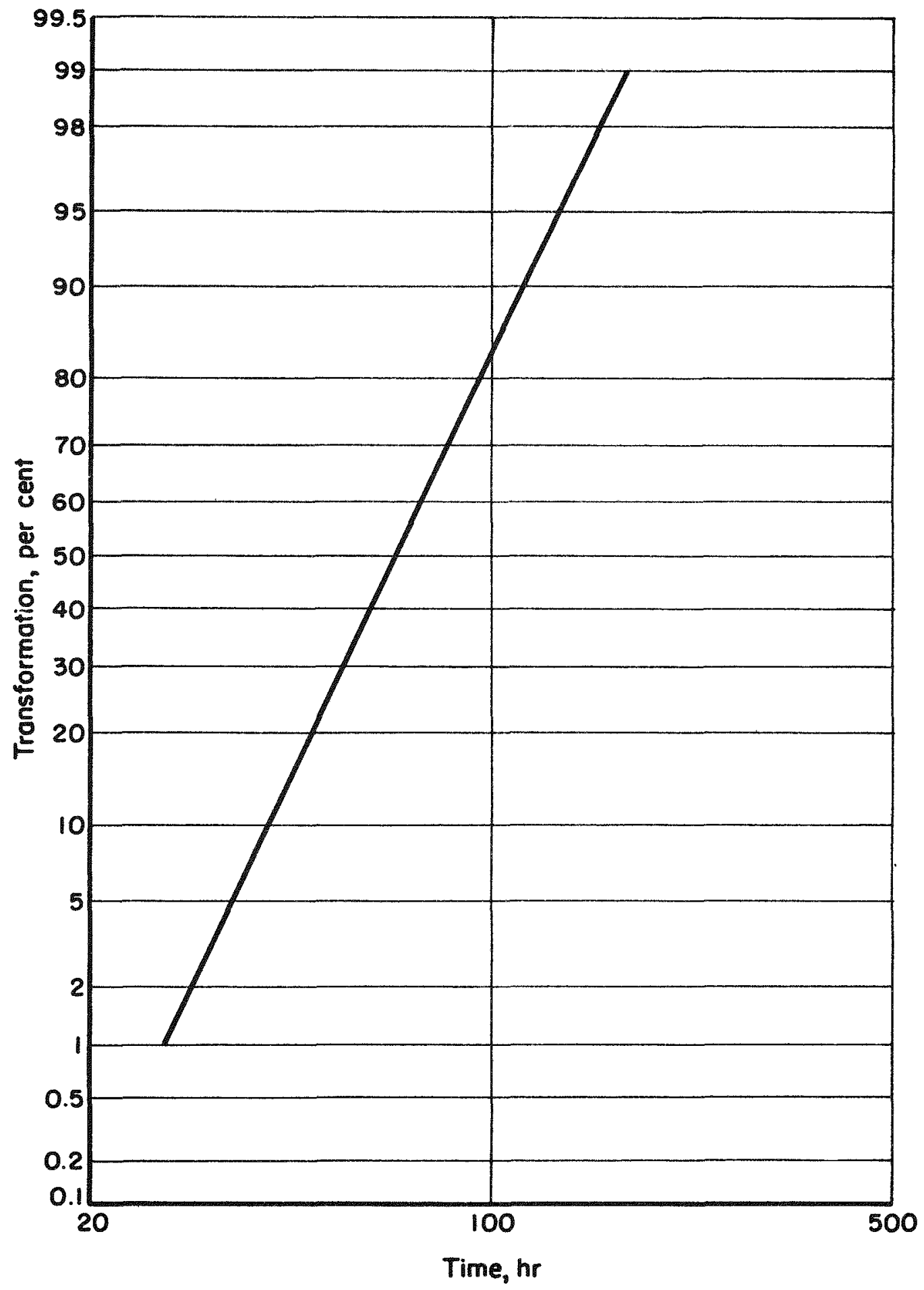

FIGURE 3. TRANSFORMATION CURVE BASED ON RESISTANCE MEASUREMENTS OF A 21 o/0 MOLYBDENUM SAMPLE DURING ANNEALING AT $500 \mathrm{C}$ 


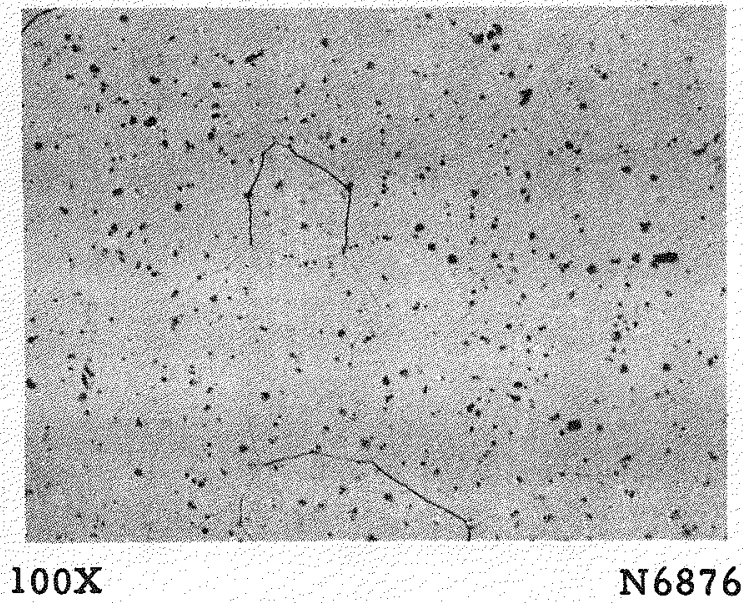

(a) Bright Field. Annealed 4-1/2 Hr $8.00 \mathrm{C}$, Water Quenched

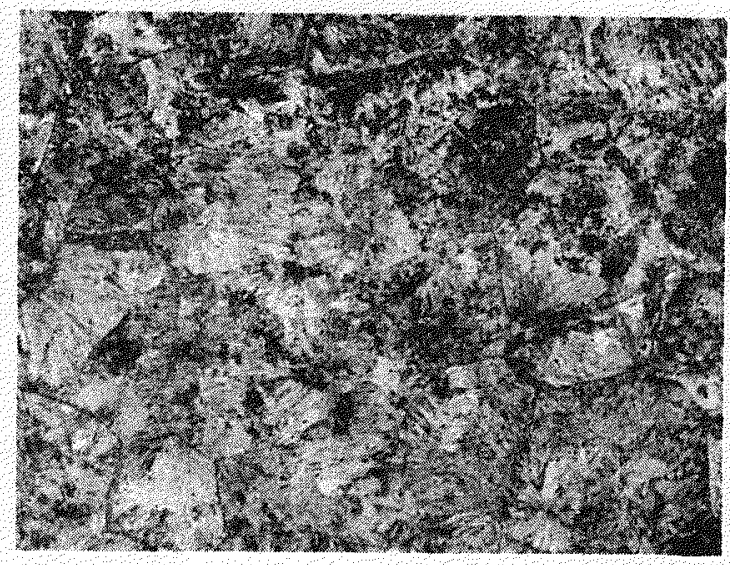

$100 \mathrm{X}$

N15393

(c) Bright Field. Annealed 4-1/2 $\mathrm{Hr} 800 \mathrm{C}$, Water Quenched. Transformed $170 \mathrm{Hr} 500 \mathrm{C}$

FIGURE 4. MICROSTRUCTURES OF 21 a/O MOLYBDENUM ALLOY

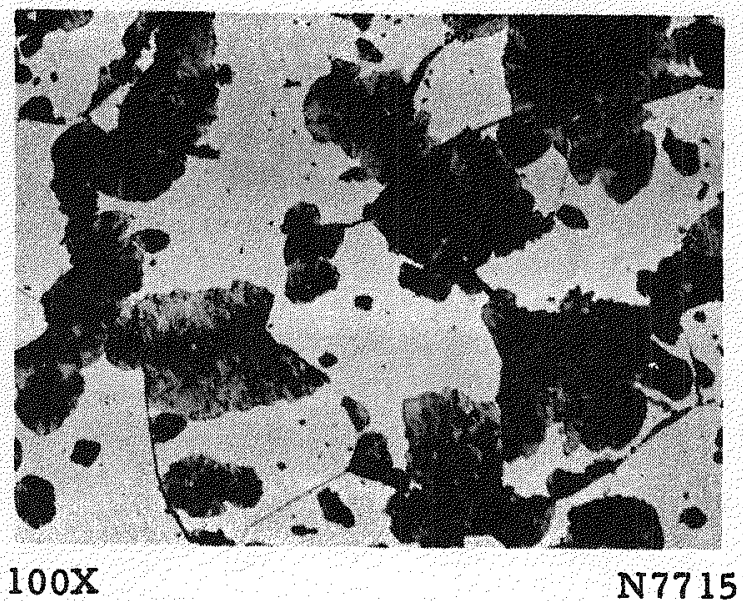

(b) Bright Field. Annealed 4$1 / 2 \mathrm{Hr} 800 \mathrm{C}$, Water Quenched. Transformed $80 \mathrm{Hr} 500 \mathrm{C}$

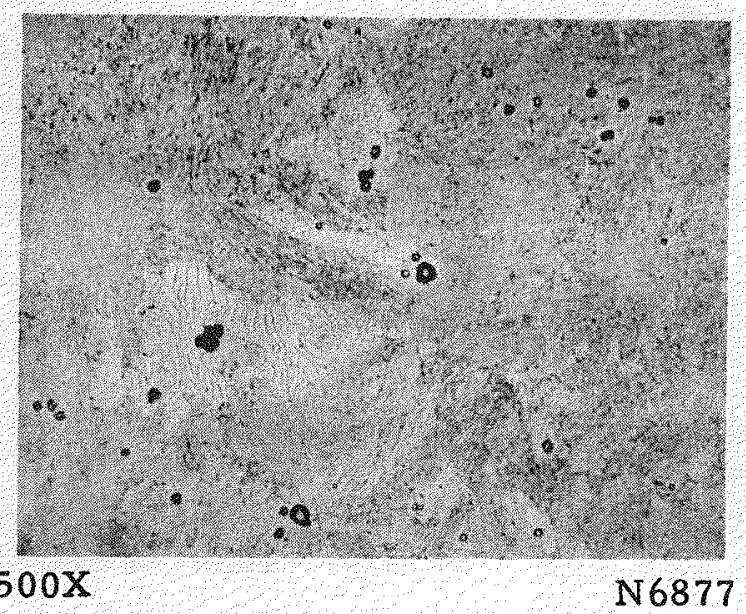

(d) Bright Field. Annealed 4$1 / 2 \mathrm{Hr} 800 \mathrm{C}$, Water Quenched. Transformed $360 \mathrm{Hr} 500 \mathrm{C}$ 


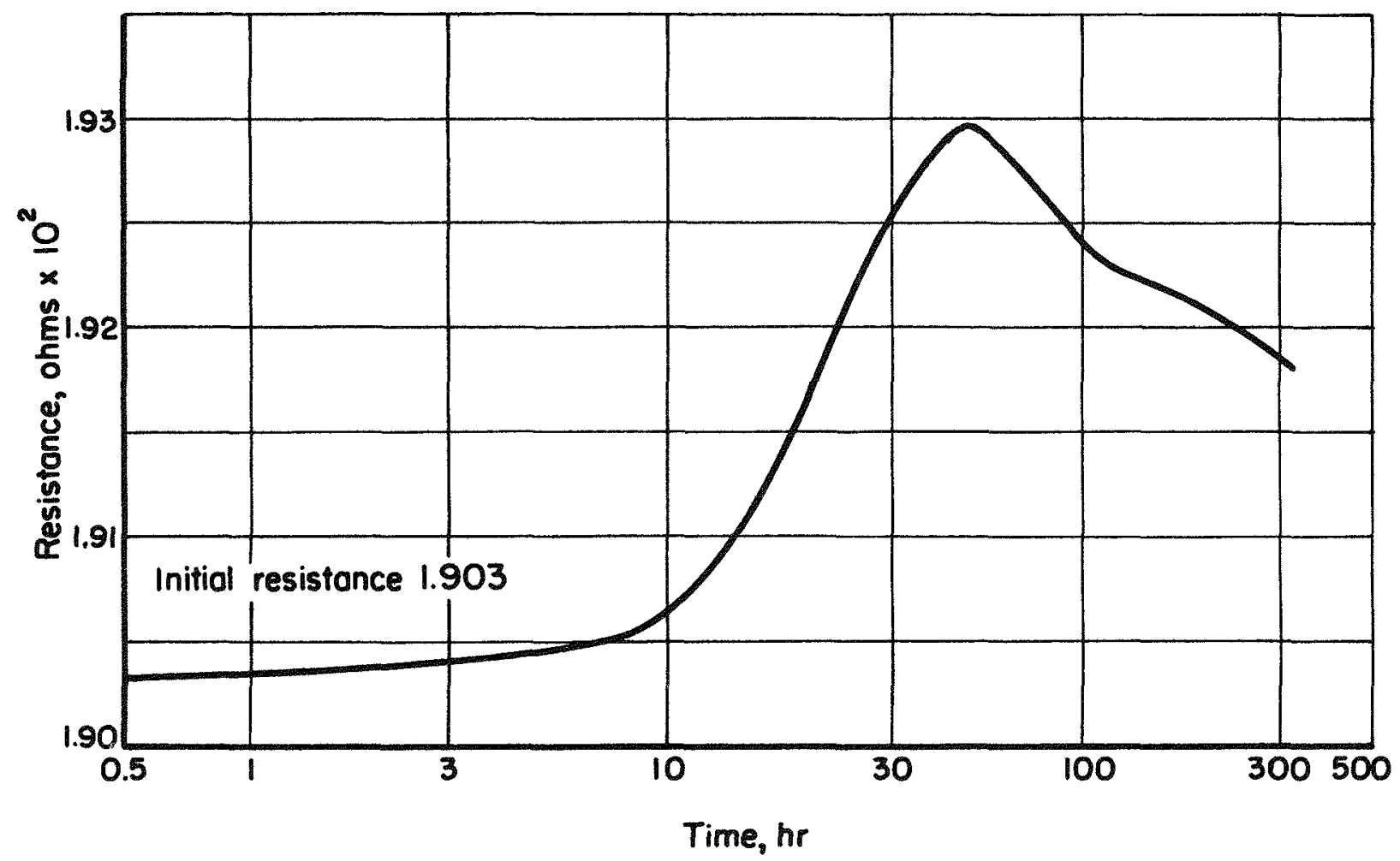

FIGURE 5. RESISTANCE CURVE OF A 26.4 a $\%$ MOLYBDENUM SAMPLE DURING ANNEALING AT $500 \mathrm{C}$ 
In the $30 \mathrm{a} / \mathrm{o}$ alloy, the initial increase occurred for 33, 28, and $43 \mathrm{hr}$ at 540,500 , and $440 \mathrm{C}$, respectively. This is shown in Figures 6, 7, and 8. Transformation of an additional specimen at $400 \mathrm{C}$ was discontinued after: $500 \mathrm{hr}$, during which time the resistance increased continuously. The initial increase at 540 and $500 \mathrm{C}$ (Figures 6 and 7) was 3.6 per cent followed by decreases of 0.3 and 0.5 per cent during the following 255 and $352 \mathrm{hr}$, respectively. At $440 \mathrm{C}$ (Figure 8), the resistance increased by 3.9 per cent during the first $43 \mathrm{hr}$ and then decreased by 2.5 per cent from the peak value during the ensuing $461 \mathrm{hr}$ at temperature.

The resistance changes are perhaps more significant when comparison before and after annealing is made of measurements taken at room temperature. When the resistance of the 26.4 a/o alloy was compared at room temperature before and after transformation, the resistance had decreased by 5.93 pex cent. In the $30 \mathrm{a} / \mathrm{o}$ alloy, the resistance of the specimens annealed at 540 and $440 \mathrm{C}$ was found to have decreased by 5.35 and 7.8 per cent, respectively. For this alloy, these decreases in resistance at room temperature compare with over-all increases in resistance of 3.3 and 1.8 per cent when measurements were taken at the temperature of transformation.

This resistance decrease is characteristic of an ordering-type reaction. The over-all increases in resistance, when measurements are made at the temperature of transformation, contrasted with the sizeable decreases, as measured at room temperature, appear to be reasonable. Apparently, the temperature coefficient of resistivity of the ordered state is much larger than that of the disordered state.

The large unit cell reported ${ }^{(2)}$ for the delta phase, as obtained by Xray diffraction, results from superlattice formation during ordering. The ordered cell is body-centered tetragonal with $\mathrm{a}_{\mathrm{O}}=6.84 \mathrm{~A}$ and $\mathrm{c}_{\mathrm{O}}=6.55 \mathrm{~A}$.

Metallographic examination of the 26.4 and 30 a/o alloys did not reveal any evidence of transformation within the grains to accompany the initial sharp increase in resistance. After $55 \mathrm{hr}$ at $500 \mathrm{C}$, corresponding to the time at which the resistance was a maximum in the $26.4 \mathrm{a} / \mathrm{o}$ alloy, small amounts of lamellar alpha and delta precipitated at the grain boundaries (Figure 9b) but there was no evidence of transformation within the gamma grains. After $170 \mathrm{hr}$, a platelike transformation along crystallographic planes was seen to be taking place (Figure 9c). Similarly, in the $30 \mathrm{a} / \mathrm{o}$ alloy, $45 \mathrm{hr}$ at $440 \mathrm{C}$ (Figure $10 \mathrm{~b}$ ) resulted in precipitation of alpha plus delta at the grain boundaries, but no transformation within the grains was observed. After $180 \mathrm{hr}$ (Figure 10c), the same platelike transformation product appeared. The resistance increase in the $30 \mathrm{a} / \mathrm{o}$ alloy, transformed at $400 \mathrm{C}$, was also accompanied by the appearance of small islands of alpha and delta at the gamma grain boundaries, but again with no evidence of transformation within the grains. 


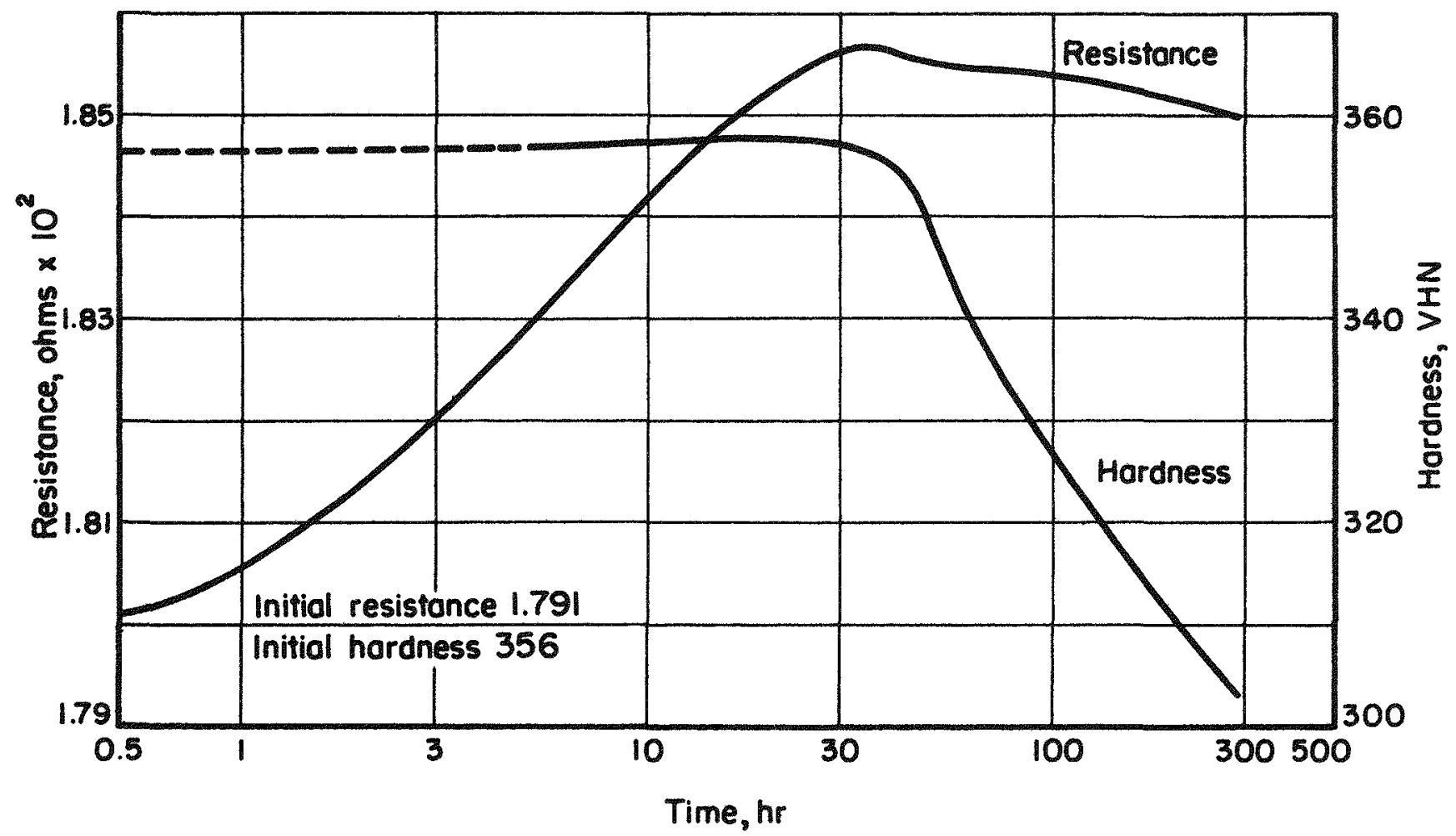

FIGURE 6. RESISTANCE AND HARDNESS CURVES OF A $30 \%$ MOLYBDENUM SAMPLE DURING ANNEALING AT 540C 


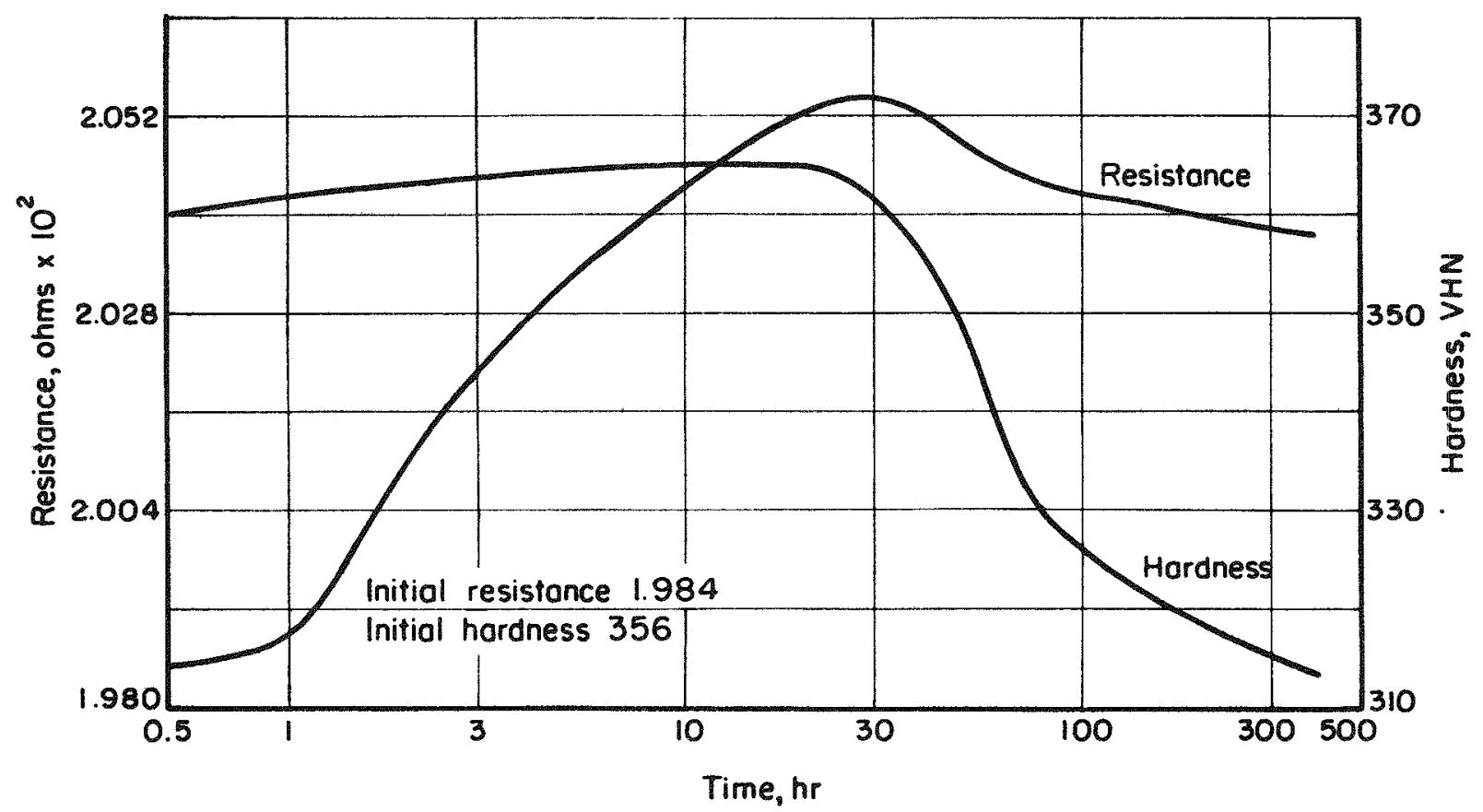

FIGURE 7. RESISTANCE AND HARDNESS CURVES OF A $30 \%$ SAMPLE DURING ANNEALING AT 5OOC 


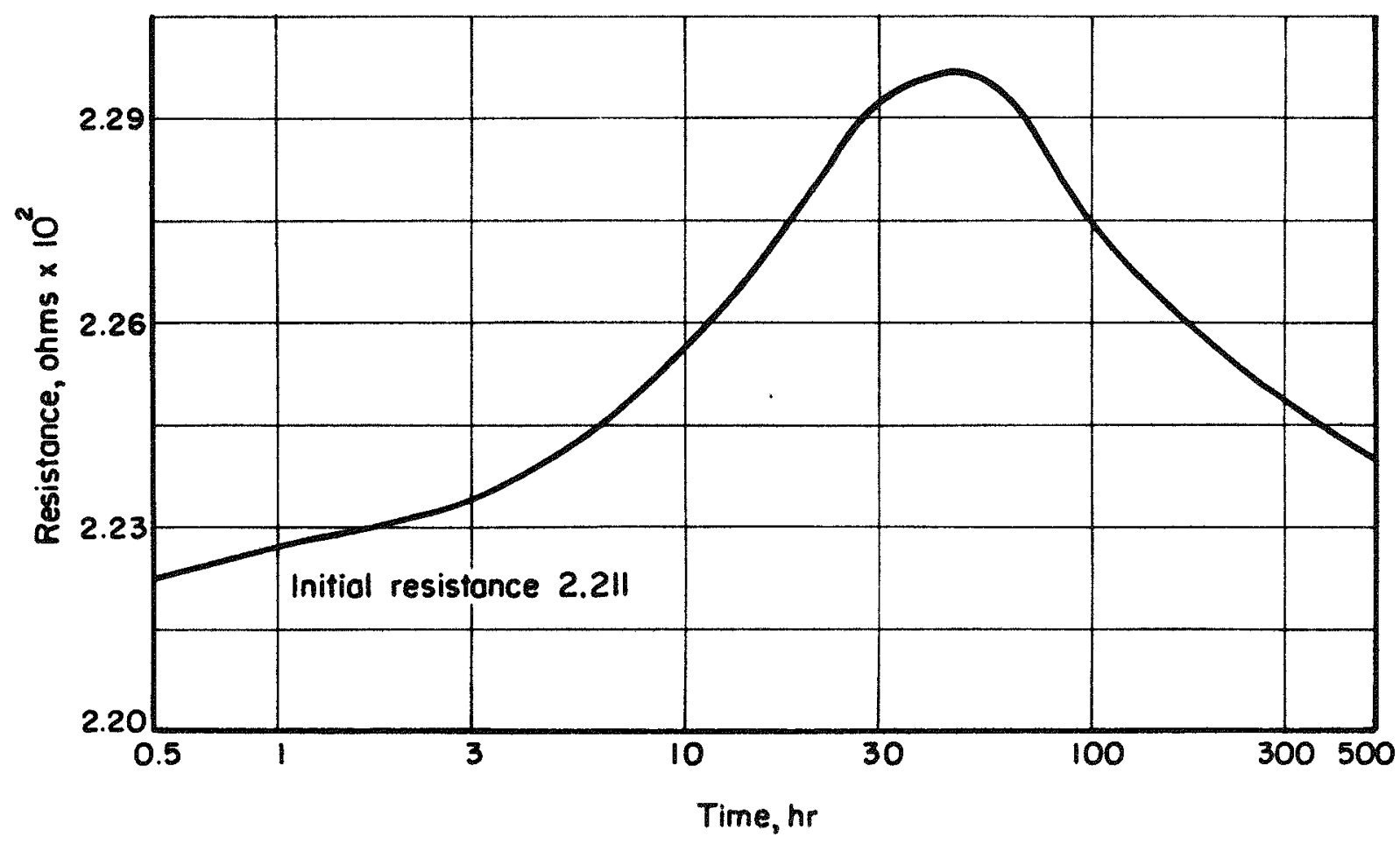

FIGURE 8. RESISTANCE CURVE OF A 30 a\% MOLYBDENUM SAMPLE DURING TRANSFORMATION AT $440 C$ 


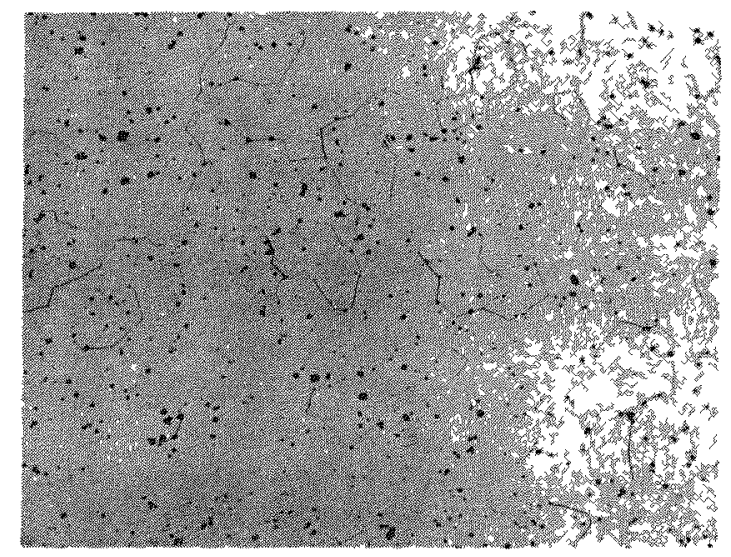

$100 \mathrm{X}$
N 17166

(a) Bright Field. Annealed 4-1/2 $\mathrm{Hr} 800 \mathrm{C}$, Water Quenched

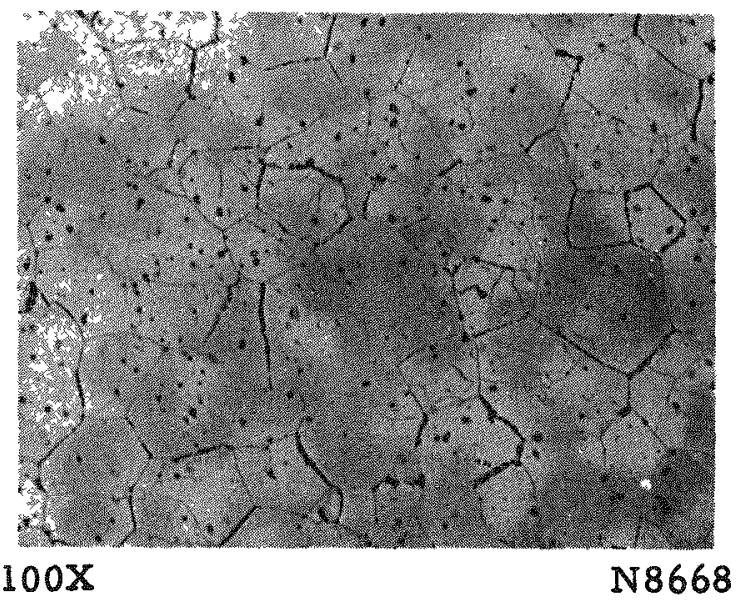

(b) Bright Field. Annealed 4$1 / 2 \mathrm{Hr} 800 \mathrm{C}$, Water Quenched. Transformed $55 \mathrm{Hr} 500 \mathrm{C}$

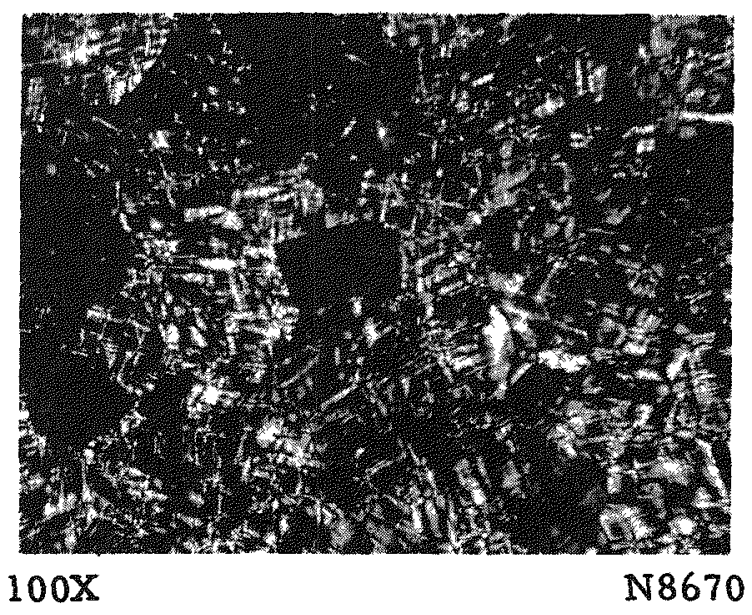

(c) Polarized Light. Annealed 4$1 / 2 \mathrm{Hr} 800 \mathrm{C}$, Water Quenched. Transformed $170 \mathrm{Hr} 500 \mathrm{C}$

FIGURE 9. MICROSTRUCTURES OF 26.4 a/o MOLYBDENUM ALLOY 


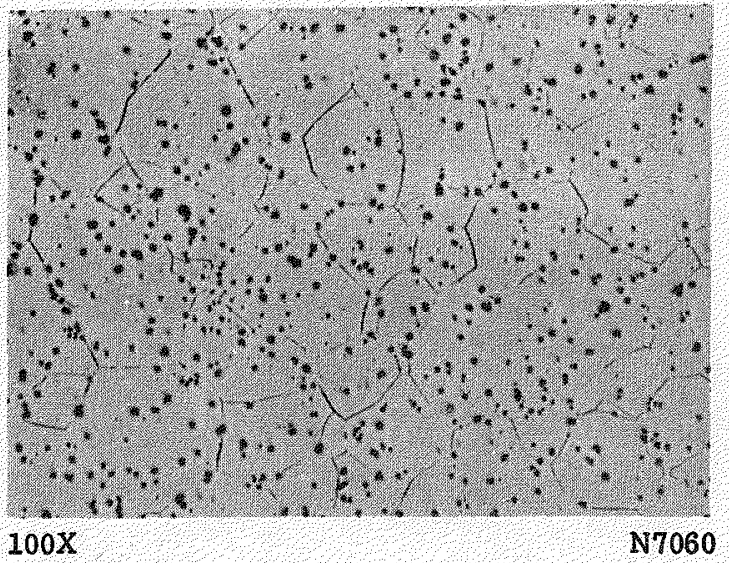

(a) Bright Field. Annealed 4-1/2 Hr $800 \mathrm{C}$, Water Quenched

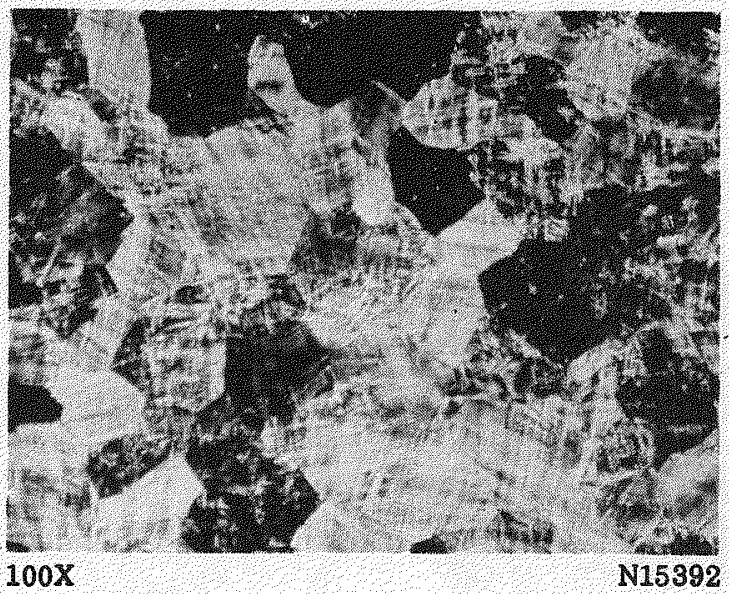

(c) Polarized Light. Annealed 4-1/2 Hr $800 \mathrm{C}$. Water Quenched. Transformed $180 \mathrm{Hr} 440 \mathrm{C}$

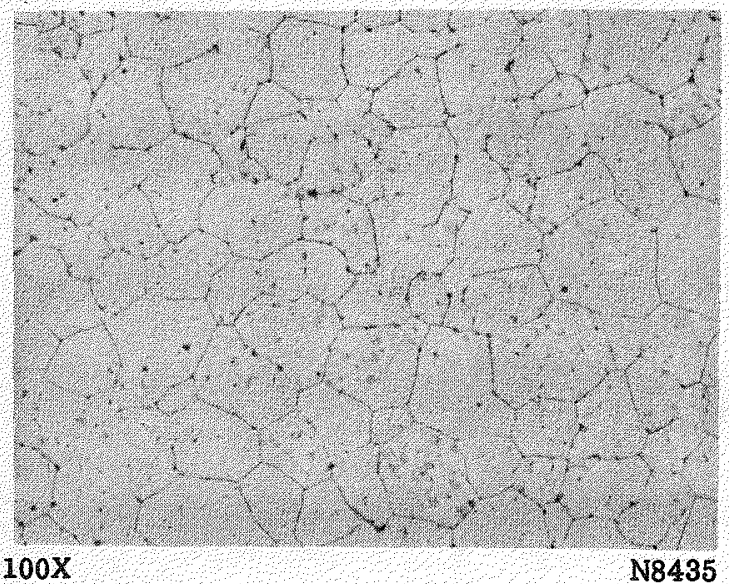

(e) Bright Field. Annealed 4-1/2 $\mathrm{Hr} 800 \mathrm{C}$, Water Quenched. Transformed $80 \mathrm{Hr} 500 \mathrm{C}$

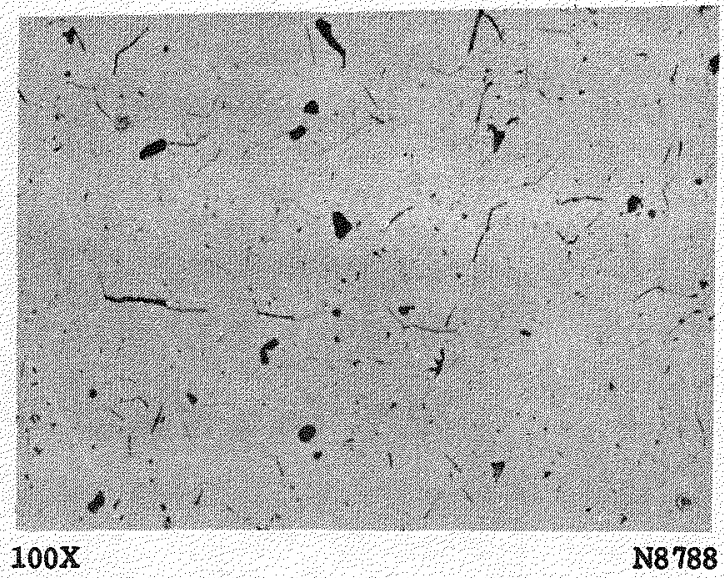

(b) Bright Field. Annealed 4-1/2 Hr $800 \mathrm{C}$, Water Quenched. Transformed 45 Hir $440 \mathrm{C}$

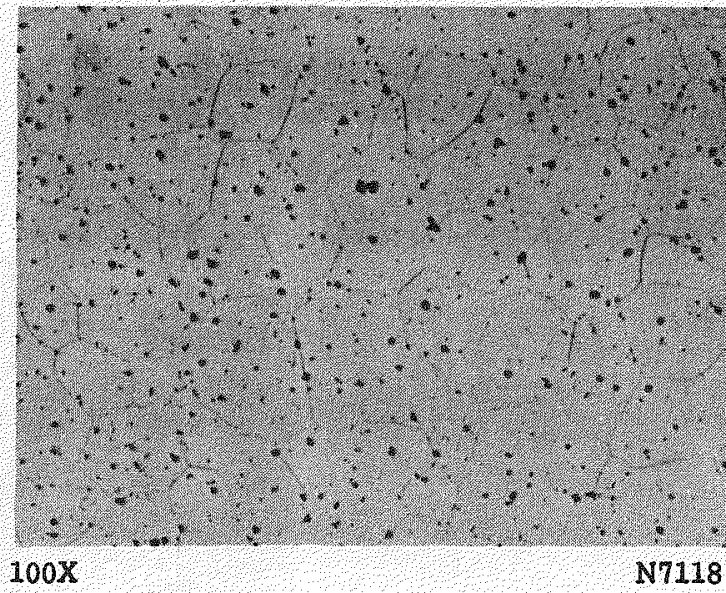

(d) Bright Field. Annealed $4-1 / 2 \mathrm{Hr} 800 \mathrm{C}$, Water Quenched. Transformed 4 Hr $500 \mathrm{C}$

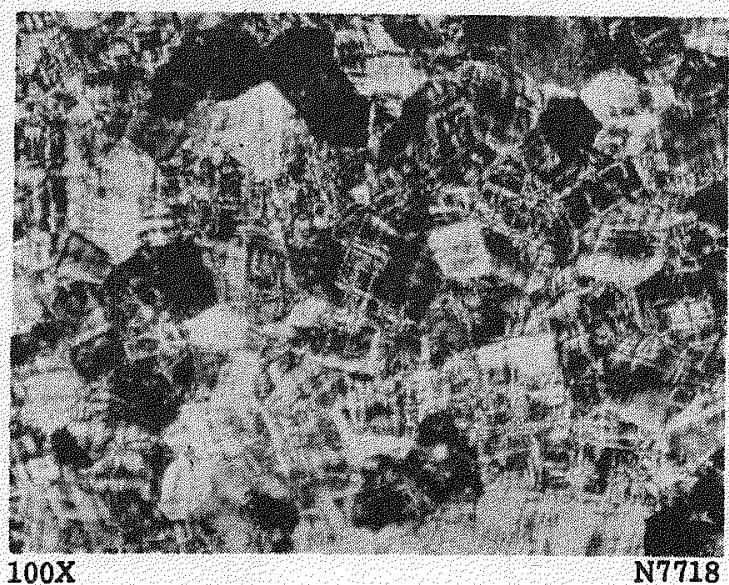

(f) Polarized Light. Annealed 4-1/2 Hr $800 \mathrm{C}$, Water Quenched. Transformed $80 \mathrm{Hr} 500 \mathrm{C}$ 


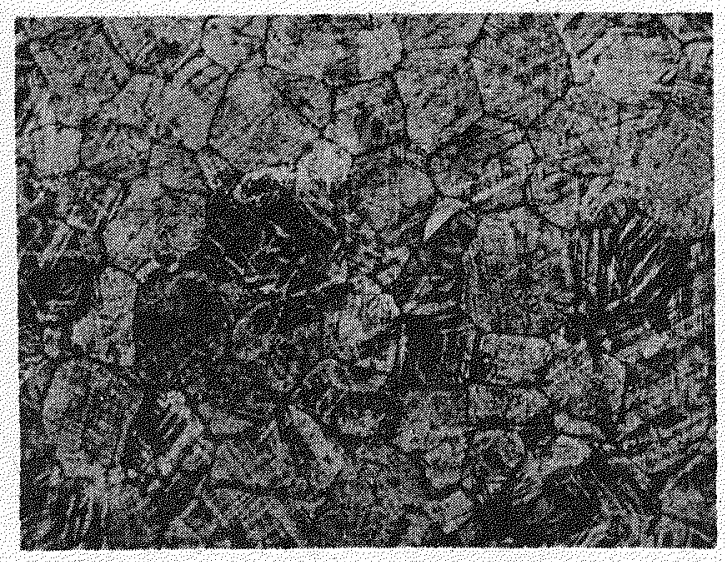

$100 x$

N8438

(g) Bright Field. Annealed 4-1/2 Hr $800 \mathrm{C}$, Water Quenched. Transformed $380 \mathrm{Hr} 500 \mathrm{C}$

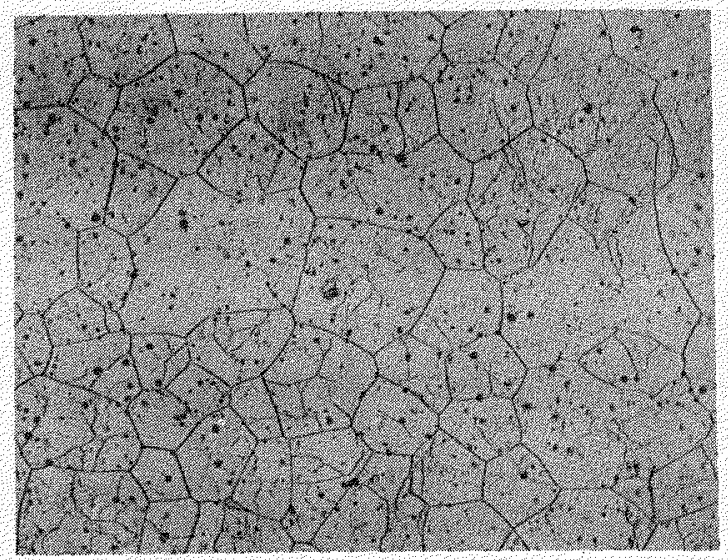

$100 \mathrm{X}$

N17165

(i) Bright Field. Annealed 4-1/2 Hr $800 \mathrm{C}$, Water Quenched. Transformed $40 \mathrm{Hr} 540 \mathrm{C}$

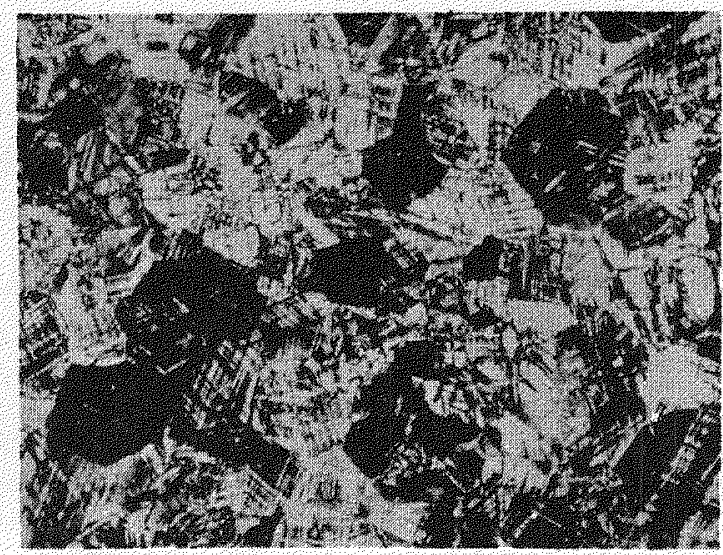

$100 x$

N7108

(h) Polarized Light. Annealed 4-1/2 Hr $800 \mathrm{C}$. Water Quenched. Transformed $380 \mathrm{Hr} 500 \mathrm{C}$

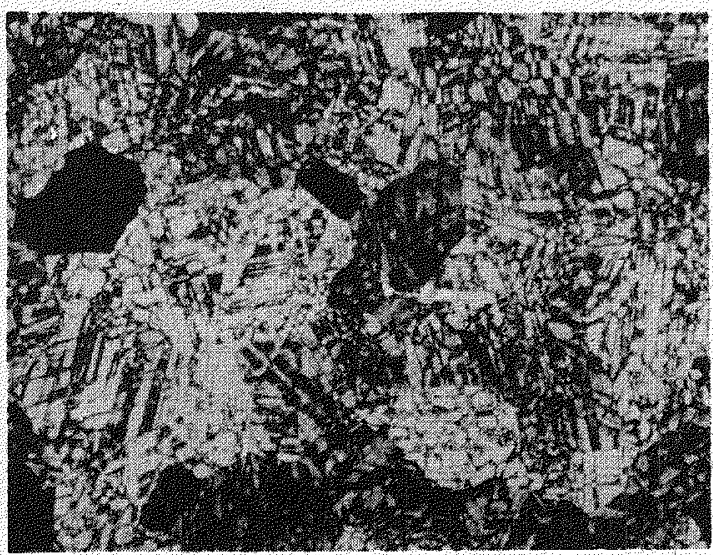

$100 \mathrm{X}$

N15391

(j) Polarized Light. Annealed 4-1/2 Hr $800 \mathrm{C}$, Water Quenched. Transformed $288 \mathrm{Hr} 500 \mathrm{C}$

FIGURE 10. (Continued) 
The presence of the alpha phase in these three specimens is in agreement with the constitutional diagram shown in Figure 1, in which decreasing solubility of uranium in the delta phase with decreasing temperature is indicated.

The $30 \mathrm{a} / 0$ alloys transformed at 500 and $540 \mathrm{C}$ showed no evidence of transformation during the initial resistance increase. Neither $4 \mathrm{hr}$ at $500 \mathrm{C}$ (Figure 10d) nor $40 \mathrm{hr}$ at $540 \mathrm{C}$ (Figure 10i) produced any great change in the gamma-quenched structure, although after $80 \mathrm{hr}$ at $500 \mathrm{C}$ (Figures $10 \mathrm{e}$ and $f$ ) the platelike structure appeared. Under bright-field illumination the effect is difficult to show, but polarized light indicates extensive transformation has begun. After $380 \mathrm{hr}$ at $500 \mathrm{C}$ (Figures $10 \mathrm{~g}$ and h), both brightfield and polarized-light techniques sharply delineate the transformed plates.

It should be noted that the transformed metallographic structures are consistent with an ordering reaction. Essentially the same platelike structures have been observed during ordering of a cobalt-platinum alloy, Co-Pt. (7)

Hardness measurements were made on the $30 \mathrm{a} / 0$ specimens which were transformed at the two temperatures, 540 and $500 \mathrm{C}$, to show pure gamma-to-delta transformations, with no initial precipitation. The hardness curves for these specimens are shown with their resistance curves, in Figures 6 and 7. The hardness curves, for both temperatures of transformation, follow the resistance curves quite closely, the hardness increasing slightly and then decreasing with time.

Both the hardness and resistance increases are assumed to be caused by strain developed in the alloy as coherent nuclei of the ordered tetragonal phase form in the gamma matrix. This induction period, which may correspond to a period of short range order, is ended when the nuclei become of sufficient size to lose coherency with the parent matrix. The hardness and resistance decrease thereafter, as the ordered plates grow at the expense of the disordered parent matrix. This period is accompanied by observable precipitation of the ordered plates.

Further evidence of a stressed condition during the initial period of transformation was observed in a series of $30 \mathrm{a} / 0$ specimens transformed at $500 \mathrm{C}$ for $2,4,80$, and $170 \mathrm{hr}$ and water quenched. The specimens annealed for 2, 4, and $80 \mathrm{hr}$ showed intergranular cracks near the edges upon metallographic examination, whereas the specimen transformed for $170 \mathrm{hr}$, as well as a sample in the initial gamma-quenched condition, showed no evidence of such cracks. Evidently, superposition of quenching stresses upon those in the material as a result of the induction period are sufficient to cause cracking. 
If the resistance curves of the 30 a/o alloy (Figures 6, 7, and 8) are compared, the peak resistances are found to occur after 33, 28, and $43 \mathrm{hr}$ at 540,500 , and $440 \mathrm{C}$, respectively. At $440 \mathrm{C}$, the resistance increased continuously for $500 \mathrm{hr}$, at which time the transformation was discontinued. This period appeared to coincide with the stage of increasing resistance at the other temperatures.

These variations suggest a $\mathrm{C}$-curve behavior for the alloy, the nose of the curve lying close to $500 \mathrm{C}$. Upon the basis of the metallographic observations, the C-curve represents the end of an induction period and the start of transformation.

In general, the transformation of the 30 a/o molybdenum alloy at 540 , 500 , and $440 \mathrm{C}$ may be regarded as essentially complete. However, the end of transformation, which may be expected to show a $\mathrm{C}$-curve behavior also, apparently was not reached, since the resistance continued to decrease even after long periods at temperature. Another possible explanation is that the resistance decrease is the result of coalescence of ordered plates.

The C-curve behavior for the alloy is a consequence of the tendency to order, which increases with decreased temperature, and the rate of diffusion, which decreases with decreased temperature. The nose of the C-curve occurs at the temperature at which these two controlling factors are balanced for optimum transformation.

\section{SUMMARY AND CONCLUSIONS}

Transformation of the 21 a/o molybdenum alloy occurs by a nucleation and growth mechanism. The alpha and delta phases are nucleated at the gamma grain boundaries and grow inward to consume the gamma grains. The decomposition products have a lamellar distribution. Resistance and hardness measurements during transformation show an induction period, a period of transformation, and finally a stage where no further change occurs.

The 26.4 and 30 a/o molybdenum alloys transform by an ordering reaction which probably occurs by a nucleation and growth mechanism. Sufficient data are available to indicate that the transformation in the $30 \mathrm{a} / \mathrm{o}$ alloy has a C-curve-type behavior. During transformation of the alloys, the electrical resistance and hardness first increase and then decrease with time, the peaks in resistance and hardness almost coinciding. Transformation is not observed metallographically until after the resistance and hardness peaks are passed.

The increased hardness and resistance during aging are attributed to strain developed in the matrix as a result of the formation of coherent 
nuclei. Precipitation, and loss of coherency, are accompanied by a decrease in resistance and hardness. The induction period, preceding transformation, and attendant $\mathrm{C}$-curve behavior origitate in the temperature dependence of the tendency of the alloy to order and of the rate of diffusion.

The transformation of gamma to delta is sluggish at all temperatures, and the rate decreases rapidly below $440 \mathrm{C}$. The optimum temperature of transformation, or nose of the C-curve, lies close to $500 \mathrm{C}$.

\section{REFERENCES}

(1) Ahmann, D., Snow, A. I., and Wilson, A. S., "The UraniumMolybdenum Binary System", CT-2946 (July, 1945).

(2) Saller, H. A., Rough, F. A., and Vaughan, D. A., "The Constitution Diagram of Uranium-Rich Uranium-Molybdenum Alloys", BMI-72 (June 1, 1951).

(3) Burkhart, M. , and Lustman, B., private communication (March, 1954).

(4) Pfeil, P. C. L., and Browne, J. D., "Superlattice Formation in Uranium-Molybdenum Alloys", AERE M/R-1333 (January, 1954).

(5) Tucker, C. W., Jr., "Discussion of the Constitution of Alloys, by P. C. L. Pfeil in the Journal of the Institute of Metals", AECD-3092 (March, 1951).

(6) White, D. W., Jr., "Transformation Kinetics in Uranium-Chromium Alloys", TID-5061 (January 31, 1952).

(7) Newkirk, J. B., Geisler, A. H., Martin, D. L., and Smoluchowski, R., "Ordering Reaction in Cobalt-Platinum Alloys", Trans. AIME, 188,1249 (1950). 